"Socio-economic implications of South Africa's foreign direct investment in Southern African development"

\author{
Samuel Augustine Umezurike \\ AUTHORS Chux Gervase Iwu (D https://orcid.org/0000-0002-6290-9864 \\ Lucky Asuelime
}

Samuel Augustine Umezurike, Chux Gervase Iwu and Lucky Asuelime (2016).

ARTICLE INFO

Socio-economic implications of South Africa's foreign direct investment in Southern African development. Investment Management and Financial Innovations, 13(3-2), 362-370. doi:10.21511/imfi.13(3-2).2016.08

DOI http://dx.doi.org/10.21511/imfi.13(3-2).2016.08

RELEASED ON Monday, 10 October 2016

JOURNAL

"Investment Management and Financial Innovations"

FOUNDER

LLC "Consulting Publishing Company "Business Perspectives"

NUMBER OF REFERENCES

0

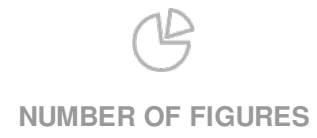

0

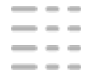

NUMBER OF TABLES

0

(C) The author(s) 2022. This publication is an open access article. 
Samuel Augustine Umezurike (South Africa), Chux Gervase Iwu (South Africa), Lucky Asuelime (South Africa)

\title{
Socio-economic implications of South Africa's foreign direct investment in Southern African development
}

\begin{abstract}
Notwithstanding its struggles to tame the high levels of poverty and inequality, South Africa is considered as a major economic hub of Africa. However, as an economic hub, there are other countries that perceive South Africa as a capitalist, neo-liberal economy that goes all out to dominate not only its neighbors in the southern hemisphere, but also many other developing nations in the continent. Therefore, the main aim of the study is to assess the socio-economic implications of South Africa's foreign direct investment in Southern Africa. As far as the authors are concerned, there is yet to be a frank analyses of the varying perspectives, as well as a holistic explanation of the clearly, yet complex relationship which exists between South Africa and many other countries in the southern hemisphere. While the authors acknowledge the efforts of several scholars in trying to juxtapoze the nuances in these relationships, they insist that there has not been a contextual treatment with due consideration for the socio-economic implications of South African business expansion in Africa. Thus, the authors sincerely believe that the paper has serious implications for emerging economies especially in Africa. Other African countries can learn from South Africa's tactical brilliance; the way it has positioned its economy as a major economic hub in Africa with illustrious attractions that are derived from sophisticated infrastructure, a good educational system, a functional health care system and world class standard ecotourism. The study was conducted using documentary analysis and, therefore, allowed the researchers to source and utilize documents, both in private and public domain, on the basis of their relevance to the research.
\end{abstract}

Keywords: democracy, foreign direct investment, public administration, Southern African Development Community, Southern African Customs Union, Southern African Power Pool, regional cooperation.

JEL Classification: H5, N27, 016, 019, 024, 055.

\section{Introduction}

As a new democracy, South Africa (SA) is considered as a major economic hub of Africa. However, reports suggest that the nation is struggling to tame the high levels of poverty and inequality. Ncube et al. (2012) decried SA's unemployment rate which stood at over $40 \%$ in 2010. Inequality in the country since democracy in 1994 remains one of the highest around the globe, because an estimated $40 \%$ of the SA national income goes to only $10 \%$ of its population. Mbeki's (2003) description of this disturbing level of inequality is captured, thus:

'Our country is characterized by two parallel economies, the first and the second. The first economy is modern, produces the bulk of our country's wealth, and is integrated within the global economy. The second economy (or the marginalized economy) is characterized by underdevelopment, contributes little to the GDP, contains a big percentage of our population, incorporates the poorest of our rural and urban poor, is structurally

(C) Samuel Augustine Umezurike, Chux Gervase Iwu, Lucky Asuelime, 2016.

Samuel Augustine Umezurike, Dr., Department of Public Administration, Faculty of Commerce, Administration and Law, University of Zululand, South Africa.

Chux Gervase Iwu, Professor, Department of Entrepreneurship and Business Management, Faculty of Business and Management Sciences, Cape Peninsula University of Technology, South Africa.

Lucky Asuelime, Dr., Department of Politics and International Studies, Faculty of Arts, University of Zululand, South Africa. disconnected from both the first and the global economy, and is incapable of self-generated growth and development'.

For the needed positive result in the socio-political economy of the rainbow nation ${ }^{1}$ to take place, a new but workable approach is required. Owing to the thesis of Moolman et al. (2006) that there is a historical link between foreign direct investment (FDI) and economic development in Europe, America and Asia, the contention, with respect to a workable strategy, was to adopt the Asian Tiger's development strategy. Generally, the Asian Tigers delivered their economic success story especially through FDI which occurred through inflow and outflow of same. Basically, the practice of Asian Tiger's FDI simply meant clinging to already established capitalist path similar to the West. Thus, leaning towards a trend whereby neo-liberalism expressed in form of deregulation and tax cuts is encouraged.

World Bank (2011) reported that SA's projected GDP growth was put at $3.5 \%$ in $2011,4.1 \%$ in 2012 and $4.4 \%$ in 2013 . But its long run projected growth rate was pegged at $3.5 \%$, while GDP was expected to accumulate its full potential by 2014 , aiming at $6-7 \%$ growth making it possible to handle the estimated $40 \%$ unemployment in SA. The expectation was that FDI would be a push factor in SA's plan towards

\footnotetext{
${ }^{1}$ Coined by Archibishop Desmond Tutu, the term rainbow nation is used to describe South Africa owing to its diverse cultures - several official languages and traditions.
} 
delivering the estimated GDP growth and socioeconomic development. This meant that SA's ability to invest beyond its territory and its favorable atmosphere to allow outside investors to invest in the country makes FDI the gateway to its economic development. This approach was considered as a thoughtful strategy to deliver a speedy development in the opinion of the political and economic policymakers of SA.

SA's FDI has especially been through private organizations, however, steadily patronized and supported by its government institutions, including mostly the Departments of Trade and Industry and International Relations and Cooperation. Between 2010 and 2011, Labor Research reported that SA was a crucial investment source of FDI in developing countries especially considering that its trade and investment capabilities are notable in almost every sector in sub-Saharan Africa. On the basis of this, SA was acknowledged as an influential player in FDI both within developed and developing countries. In 2004, barely 10 years after apartheid in the country, SA companies invested in more than 600 projects in sub-Saharan Africa (Labor Research Service, 2010/2011). This is impressive for a developing country such as SA.

However, while SA has sought to invest freely in Africa especially in its immediate sub-region, Southern Africa, it has piloted policies that militate against free trade between it and the rest of Africa. For example, it stopped the initiative of Southern African Development Community (SADC) on free movement of people, but it was quick to put on the table free trade among SADC states (see Umezurike, 2015). This scenery of ambivalence with regard to SA's political and economic policy in Africa has been subjected to different interpretations by many (see Umezurike, 2015). Many analysts hold the view that SA acts in its national interest, while at same time seeking hegemony and/or attempting to position itself as a sub-imperial outpost in sub-Saharan Africa (see also Alden \& Soko, 2005). The contradictory characterization of this kind is not yet completely presented in literature and has, thus, left a big gap in understanding the overall spectrum of SA's policy towards subSaharan Africa. Nathan (2005), Ndlovu (2010), Borer and Mill (2011) and Alden and Schoeman (2013, p. 215), argue that SA's relations with Africa are largely underlined by African renaissance, while, on the other hand, Miller (2008), Bond (2013), and Luiz and Stewart (2013) treat it mostly from the angle of neo-imperialism. In our view, many have not juxtaposed the varying perspectives with a view to analyzing the nuances and providing a holistic explanation of a clearly complex relationship which may not be easily described conclusively as either black or white. Even if scholars have drawn such a conclusion in either way, there has not been a contextual treatment of any of such conclusion with due consideration for the socio-economic implication of South African business expansion in Africa. We are also sincerely inclined to believe that the paper has serious implications for emerging economies, especially in Africa. SA's steps can serve as a lesson for other African countries to learn from its tactical brilliance; the way it has positioned its economy as a major economic hub in Africa with illustrious attractions that are derived from sophisticated infrastructure, a good educational system, a functional health care system and world class standard ecotourism. The focus of the paper as illustrated in the foregoing statement underscores its significance.

This paper is organized as follows. The next section presents a narrative on the methodology used for this paper. Afterwards, there are three significant sections namely a general overview of SA and SADC relationship, SA and the Southern African Custom Union (SACU), and the Southern African Power Pool (SAPP). These sections make up the literature and are intended to provide the substantive argument that SA continues to impact on the SADC political economy because of its neo-liberal policy which mainly serves as the backbone of its relations with SADC member countries. Thereafter, we present our concluding remarks.

\section{Methodology}

This study was carried out using documentary analysis method which allows researchers to study, and make sense of written documents, which exist either in the public or private domain (Payne \& Payne, 2004; Mogalakwe, 2006). This definition suggests that researchers determine the relevance of the documents that they consult on the basis of their significance to the study. Dey (2005, p. 105) argues that "in documentary analysis, the criteria for selecting documents, or for focusing on particular extracts, should reflect the issues on which the researcher is seeking evidence".

\section{Literature review}

\section{General overview of South Africa's relations with the SADC}

SADC was formed following a comprehensive consultation among heads of states of the democratic southern African states who signed the SADC Treaty and Declaration on August 171992 to change Southern African Development Coordination Conference (SADCC) to SADC. This transformation led to 'a shift in the objective to include economic integration following the independence of all the southern African states' (Matsoso \& Iwu, 2016). 
Since 1992 when it was formed, SADC declared that the sub-region may not only embrace economic integration, but also social, political, and security cooperation. SA became a member of the group in 1994 after the historic end of racial rule in the country (Alden \& Pere, 2009). It is evident that SA's presence has been felt through its domination in trade and investment over other African states. For example, in 2013, SA's exports increased to R846 billion from R817 billion in 2012, while imports increased to R921 billion from R852 billion within the same period (African Economic Outlook, 2014). This nearly doubled the trade deficit of SA between 2012 and 2013 which moved from "R40 billion to over R74 billion" (African Economic Outlook, 2014). Top on the list of SA's major exports are gold, iron ore and concentrates, coal, and platinum, while petroleum, original equipment components, electrical machinery, equipment, vehicles and accessories are the main imports. African Economic Outlook (2014) also affirms SA's FDI improvement in Africa from R37.5 billion in 2012 to R47.4 billion in 2013.

By 2001, less than 10 years of democracy, SA had become a notable investor in SADC, having been rated as the second biggest investor in the sub-region. According to Games (2003), SA investment in the sub-region was worth more than R14.8 billion with multi-state deals leading at R27 billion in 2001 (Games, 2003). Games (2003) also stated that SA dominates the southern African sub-regional economy where it produces more than $80 \%$ of the sub-region's GDP as on 2003. Evidently, this status of SA in the sub-region has not changed. The estimate of SA's economic product was US\$160 billion. This is more than the output of 13 other SADC countries' output put together at about US\$33 billion (Games, 2003; Alden \& Soko, 2005). By the year 2000, SA's FDI in SADC states was projected to be more than US\$5.4 billion.

Games' (2003) analysis shows that:

'In 2001, just nearly a decade after apartheid, South African Airways (SAA) had invested US\$20 million in Air Tanzania; US\$6 billion by Eskom Enterprises in the Inga project in the Democratic Republic of Congo (DRC); US\$56 million by Sun International in Zambia; US\$142 million investment by Vodacom in Tanzania and an additional US\$139 million investment in the DRC; US\$53 million by Pretoria Portland Zimbabwe in merger activity in Zimbabwe; a US $\$ 860$ million investment by BHP Billiton, the IDC and Mitsubishi in the development of the Mozal aluminium smelter in Mozambique; and a further investment of US\$1.1 billion by Sasol in the Pande and Temane gas fields in Mozambique in Southern Africa' (see also Alden \& Soko, 2005; Alden and Pere, 2009).
We appreciate the fact that Zimbabwe was the biggest trading partner of SA until 2002 when things turned around because of SA's interest. However, SA's dominance and protectionist interest brought in swift change in the trade relations of the two countries and Zimbabwean economic crisis did not help matters since it has not made it competitive in the global political economy, especially with SA. SA's Preferential Trade Agreement with Zimbabwe which began in 1964 was not renewed when it expired in 1992. After expiration of the agreement, SA's response was to raise tariff on textiles and clothing from Zimbabwe from $25 \%$ to $75 \%$ albeit with assurance to lower it to $30 \%$ by 1996 and $20 \%$ by 2000 (Alden \& Soko, 2005; Alden \& Pere, 2009). The concern is not whether SA may be able to implement the tariff reduction, but the decision depicts it as a country with neo-imperial ambitions, considering the timing since the hike in tariff came when Zimbabwe's economy began to deteriorate and was not able to contain the fierce competition of SA's textile and clothing industry. It was a grand betrayal of a friendly state that supported SA's struggle against apartheid with everything within its diplomatic arsenal.

Nearly a decade after apartheid, more than 250 firms of SA's origin got involved in over 320 projects and partnerships in Mozambique, accounting for investment of over US\$1330 billion by the year 2003 which represented about $49 \%$ of its FDI between 1997 and 2002 (Games, 2003; Alden \& Soko, 2005; Alden \& Pere, 2009). Our major argument with South African involvement in investment projects in African continent is that while the assumption is that the private groups of SA origin are at the forefront, their companies enjoy full support and protection of the state. Such attitude is clearly imperialist in nature and by our assessment, it appears there is a clear political undertone to the business initiatives of SA companies especially in Africa where it has used projects such as African renaissance, NEPAD, and its peer review mechanism to penetrate African markets at advantageous positions. This form of diplomacy that SA engages in allows it to receive concessions from African states when investing in Africa (see Umezurike, 2015). In many instances, the South African companies that operate in Africa are publicowned, state and private partnership or completely private, but the state promotes the idea of increased investment in trade in sub-Saharan Africa. The magnitude of SA's investment in sub-Saharan Africa instilled fear into African countries. For example, SA's bilateral trade with Tanzania which started in the 1990s rose to US $\$ 443$ million in 2000 instilled fear of domination of Tanzanian economy by SA'S companies (see Games, 2003; Alden \& Pere, 2009). This fact holds true in other African countries such as Nigeria, Kenya and Zimbabwe. 
Understandably, SA's trade with other African countries is clearly skewed in the former's favor. SA's exports to Africa, are predominantly finished goods, its export rose from U\$1.3 billion in 1994 to US $\$ 5.9$ billion by the year 2003, while imports to SA increased from sluggish base of US $\$ 0.4$ billion to US $\$ 1.2$ billion between 1994 and 2003 (Games, 2003; Alden \& Soko, 2005). European Union (EU) remains the largest investor in SA, accounting for about $90 \%$ of the total FDI inflows into SA. Investment from the United Kingdom is more than investment from all other countries put together and it accounts for more than $3 / 4$ of the total investment inflow into SA. The Americas and Asian Tigers made up the other top list of investors in SA, while Africa is pushed to the bottom. If SA is serious about its supposedly African renaissance agenda which it claims underlines its relations with Africa, it would not have Europe, Americas and Asia as its top investors or trading partners. Our view is that it is unlikely that any country in Africa may have the capital power and techniques to outperform Europe, America and the Asian Tigers in South African market. We, therefore, argue here that SA may as well float necessary measures that may provide companies from African countries the opportunity to compete in South African market. Such measures may include technology transfer to its immediate neighbors, tariff concessions and tax cuts for companies of African origin operating in SA.

African attractiveness research examined FDI projects carried out in Africa from 2007 to 2012, a key period in investment in the region and noted that SA distinguished itself as gateway for both in inflow and outflow of investment in Africa. This, according to Ernst \& Young, was so especially because of the positive lower risk, relatively big size of the economy, its world standard infrastructure, relatively big market, and reasonably large investments in fixed capital assets. However, SA at best acts as a 'deputy investor' in Africa, since a high proportion of capital for South African investors comes from Europe, America and Asia (see Umezurike, 2015).

Africa has an estimated population of more than 674 million with a projected per capita income of $\$ 460$ per annum (Wannenburg, 2004). However, SADC with about 208 million people produces more than $50 \%$ of the GDP of Africa. To view it from another angle, SA produces over $80 \%$ of the GDP of SADC. We argue that SA's dominance in Africa's political economy mostly relies on the lack of capacity of most African states to meaningfully engage in the manufacturing industry and services. Sub-Saharan Africa produces mostly raw materials which are exchanged unfairly in the international market. As a result of this unequal exchange, uneven relations developed between SA and its neighbors. For example, Nigeria has unequal relations with SA, because Nigeria is highly de-industrialized, while its foreign earning is dependent on primary goods/raw materials. SA, on the other hand, produces some level of finished goods which it exports to other parts of Africa at a more lucrative price than Nigeria's sale of primary goods.

Summarily, SA's comparative advantages over SADC group members and Africa in general is clearly based on its strength in world standard service-based economy, sophisticated management technique, relatively large domestic economy, high level capitalized finance industry and a relatively workable majority rule since 1994 (Ernst \& Young, 2013). These are prestigious factors that project it as a gateway of foreign investment in Africa especially for those that are still sceptical about African market, thus, positioning SA as the ideal location for capital globalization, capital transfer and investment in the African region. This is further made possible because of SA's edge over other African states visible in infrastructure, technology and modern management techniques. This has positioned SA to play an important role in subSaharan Africa as the main source of FDI. SA earned $5^{\text {th }}$ place in the ranking of FDI projects in sub-Saharan Africa particularly from 2003 till date (Ernst \& Young, 2013).

Analysts argue that if investment into SA is striped from investment into Africa, SA becomes the single largest investor in FDI projects in African continent (Ernst \& Young, 2013). South African investment into Africa has helped it to reduce unemployment, poor service delivery and further assists its postapartheid reconstruction effort. The SA's trends in FDI in African market are rated in the following form: the cumulative new projects from 2003 to 2012 was $5^{\text {th }}$ position in ranking, rise in FDI new projects from 2003 to 2012 was $536 \%$, while 2012 increase in new projects of FDI was 23\%; compound growth in new projects of FDI from 2007 to 2012 resulted in $57 \%$; jobs created by FDI of SA in Africa from 2003 to 2012 was 45 776; and the top 6 African country destinations for SA's firms' new FDI projects from 2003 to 2012 include Nigeria, Ghana, Namibia, Zambia, Angola, and Mozambique (Ernst \& Young, 2013).

In the State of the Nation Address by President Zuma on the July 17, 2014, he clearly stated that SA's trade with Africa was on the rise as the continent had become more relevant to the country's trade than other continents. He maintained that SA's investments in sub-Saharan had risen to R32.3 billion in 2013 from R5.5 billion in 2002 (Zuma, 2014). President Zuma reiterated: 
'Our exports into the continent are also increasing each year, having been at $28.5 \%$ up from $22.6 \%$ in 2002. SA will continue to champion broader regional integration through the $S A C U, S A D C$ and the envisaged Tripartite Free Trade Area that spans Eastern and Southern Africa'.

However, President Zuma did not have anything else to tell the nation on SA's relations with African countries other than praising SA's business leaders and groups operating in sub-Saharan Africa on their achievement of increased trade in sub-Saharan. In short, President Zuma failed to explain how the rise in SA's trade and investment volume in sub-Saharan Africa had reinvigorated African renaissance projects. After all, the socio-economic experience of other African countries has not improved despite SA's continued presence in the global economy. In fact, Alden and Schoeman (2015) are of the view that SA's supposedly representative position in Africa has not transformed the way Africa is viewed in the global community. They claim that evidence is in SA's membership of G-20, BRICS, and elections into UN Security Council which has failed to change the world power transfiguration to African favor. Essentially, SA business expansion and success story have not necessarily favored the continent.

\section{SA and the Southern African Custom Union (SACU)}

SACU is the oldest known customs union in the history of the world. Its history dates back to 1910 due to the signing of the Customs Union Agreement between the Union of SA and the 3 territories under British control (Draper et al., 2007). SACU is made up of Botswana, Lesotho, Namibia, Swaziland and SA. Alden and Pere (2009) view SACU as an express image of hegemonic position of SA in its immediate sub-region. Once SA democratized, ANC's led government demonstrated its desire to maintain its omnipresence within SACU. The ANC government followed a favorable course through its decision to renegotiate SACU. The review of agreement and renegotiation of SACU was a major economic and political transformation/reform of democratic SA in its relations with sub-regional counterparts. Precisely on October 21, 2002, all the member countries of SACU consented by signed agreement to allow the renegotiation of SACU (Alden \& Soko, 2005; Alden \& Pere, 2009).

SA's intention to pursue reform of SACU was undoubtedly targeted at delivering a new model of revenue allocation formula more advantageous to its national interest, as well as benefit for its gigantic economic size when compared to its SACU counterparts. Alden and Pere (2009) wrote:
'The new formula was made up of a customs, an excise and a development component. The new formula set an agreement of custom revenue sharing according to intra-SACU imports. The excise sharing would be according to the size of each of the SACU member states' exports through a development formula'.

Alden and Soko (2005), Alden and Pere (2009) are, however, of the view that SA benefitted from the new formula owing to its strong economy among SACU and may, therefore, keep about $80 \%$ of the excise duty which reflects its economic size; only $15 \%$ of the revenue may go into stabilization fund of the group. The discussion points to the fact that economic opportunity of SA superseded the common interest of SACU group. SACU at best serves the economic interest of SA, but has failed to address the needs of the poorer states who are members of the group. We are of the view that the $15 \%$ earmarked for the stabilization fund is too little to make any serious socio-economic impact with regard to other smaller, but poorer neighboring economies.

\section{Southern African Power Pool (SAPP)}

The speed flows of the Zambesi and Congo Rivers are 10 and 100 folds more than that of Orange River of SA. The projection is that the Congo River might be able to power more than 100000 megawatts of electricity. In order to make adequate use of the potentials of these rivers, it became necessary to form SAPP (Rothkegel, 2013). The economic motives that exist for the share of the electricity among the SADC is recognized and SA moved swiftly in 1995, the year SAPP was formed to benefit from it. SAPP became the forum for SA to achieve its dream of establishing advantageous relations with its neighbors and for it to be more electrified. The electricity networks of neighboring BLNS states are structurally shaped to be offshoots of the SA's ESKOM network. In fact, with the establishment of SAPP group in 1995, ESKOM became a major electricity generator in the subregion (Economic Consulting Associates Limited, 2009, see also Umezurike, 2015).

The trading counterparts of ESKOM in the continent particularly SAPP group members depend on ESKOM for more than $80 \%$ of their required energy. The socio-economic implication of this for the entire sub-region would be negative if electricity supply is cut or reduced either on technical, political or economic grounds (Economic Consulting Associates Limited, 2009). The energy dependency is another form of established unequal relations between SA and its fellow SAPP members. The SAPP's major Pool Plan is projected to require a fund of more than US\$83 billion to add more than 
$57000 \mathrm{MW}$ by the year 2025 (Economic Consulting Associates Limited, 2009, see Umezurike, 2015). This is projected to be two times over the SAPP's energy generation capacity at present. In order to generate $57000 \mathrm{MW}$ that is required, the sum of US\$5 billion was needed to balance the deficit by 2013 (Economic Consulting Associates Limited, 2009). The possible means to raise US\$5 billion was for SA to postpone its ambition to develop nuclear power capability project.

The membership of SAPP group is strictly reserved for the national electricity utilities of member states except for Hidroelectrica de Cahora Bassa (HCB) that was given the opportunity to occupy temporary observer position in the 3 sub-committees of SAPP (Planning, Operation and Environmental) before the limitation was implemented (see Leary et al., 1998; Aldrich, 2000; Zobaa, 2005; Merven \& Gielen, 2012). The 1995 agreement by SAPP member states was intended (1) to expand electricity trade, (2) to reduce energy costs, and (3) make supply more stable for the sub-regional twelve national utilities of Angola's Empresa Nacional de Electricidad (ENE), Botswana Power Corporation (BPC), Democratic Republic of Congo's (DRC) Societe Nationale d'Electricite (SNEL), Electricidad de Mozambique (EDM), Electricity Supply Commission of Malawi (Escom), Lesotho Electricity Corporation (LEC), Namibia; NamPower, South Africa; Eskom, Swaziland Electricity Board (SEB), Tanzania Electric Supply Company (Tanesco), Zambia Electricity Supply Corporation (ZESCO) and Zimbabwe Electricity Supply Authority (ZESA) (see Zobaa, 2005; Merven and Gielen, 2012; Rothkegel, 2013). The idea behind the formation of SAPP is to provide members with the benefit of sharing nature's gifts of resources such as oil, gas, coal and water and to use those for energy generation and consumption (see Umezurike, 2015). SAPP also facilitates the exchange of expertise and information that can enhance electricity production and consumption within southern African sub-region. In fact, SAPP remains a forum for a shared vision of electricity trading deals among member countries. However, SAPP group has provided SA the opportunity to have the most electrification in sub-Saharan Africa, rated at more than $70 \%$ at present.

Nevertheless, SA experiences unprecedented low reserves of energy beginning from 2000s until date. This is evident in the periodic shut down of electricity supplies to both residential and industrial customers since 2008 with residential areas suffering more erratic electricity supply (Scott et al., 2011) although there were times that SA's mines were shut down because of the electricity crisis. SA is the only country in sub-Saharan Africa that possesses a nuclear plant capability, and more nuclear plants are expected to be functional by 2023. This is in accordance with SA's goal of trimming down its use of coal from $90 \%$ to below $70 \%$ by 2030 (Scott et al., 2011). So far the analysis shows that SA is the giant electricity producer, consumer, importer and exporter within SAPP. The structure and configuration of SAPP provides ground for some form of unequal relations between SA and all the other group members.

Our view is that Africa has much to learn from SA's strategy of entrenching strong presence in the international political economy and its ability to produce finished goods and acquire foreign markets, especially in Africa. We argue also that South African presence in African markets has not transformed African position in the international political economy. The strong presence of SA companies in Nigeria, Zimbabwe, Tanzania, Mozambique and other African states has failed to transform the socio-economic condition of these countries. The results are the same in Nigeria, Tanzania, DRC and Zimbabwe despite South African success story in business and trade expansion in those countries. The formation of SADC, SACU and SAPP and the continuous south africanization of African economy in diverse sector has not yet led to any serious improvement in the socio-economic condition of Africa.

\section{Discussion}

The inception of democracy in SA positions it as a gateway to capital globalization which provided it the opportunity to put right the capital base in order to achieve balance of payments (du Plessis \& Smit, $2005,2007)$. The projection was that flows of foreign capital that occurred mainly through FDI may contribute immensely to the financing of investment and development of the country. Nevertheless, the projection has not completely reflected positively because of its diverse sociopolitical and economic problems. The problems are visible in the fluctuating market value of the rand, strikes/unstable labor relations, xenophobia, electricity shedding, inequality, poor basic and higher education standard, lack of skilled manpower and poverty. According to du Plessis and Smith (2005), as well as the International Monetary Fund (2005), these negative conditions have reduced FDI inflow into SA.

We argue that state should take responsibility in this regard due to its policies. For example, President Zuma's State of the Nation Address of 2015 reiterated the state's position not to permit foreign citizens to own land in SA. Emphasizing the state policy position on land ownership in SA, President Zuma indicated that the intention was to permit 
foreign citizens to lease land only on long term basis. In our view, this may be ground to deter international investors from SA. In fact, the 2011 World Investment Report of the UN Conference on Trade and Development (UNCTAD) claims a notable decrease in FDI inflows into SA. Elumelu and Brenthurst (2013) reported that FDI into SA generally slowed down from $\$ 5.4$ billion for the period of 2009 to $\$ 1.6$ billion in 2010. Evidence points to a drop of more than $70 \%$ in 2010 and over $80 \%$ from the $\$ 9$ billion peak reached in 2008, respectively. Whether the inflow of FDI into SA is on the increase or not since 1994, SADC countries are not noted among those who play crucial roles. On the other hand, SA's investment outflow is clearly on the rise including investments in Africa and beyond. On a general note, the outflow of investment from SA into African continent is particularly on the increase. UNCTAD (2005) reported that FDI of SA firms in Africa doubled just after 10 years of majority rule in the country. 34 high ranking 100 JSE-listed firms recorded 232 investment projects in 27 sub-Saharan African states, creating above 71,874 jobs as at 2005 . This accounted for above $22 \%$ of the FDI in SADC between 1994 and 2004 (UNCTAD, 2005; Umezurike, 2015).

SA's Government Employee Pension Fund is one of the top five shareholding firms listed on the JSE since 1994. In other words, government employees, and their unions have a significant investment in MNCs of South African origin that operate in subSaharan Africa (Labor Research Service, 2010/2011). South African government is involved in these investment projects although the private sector is involved at all levels. While we frown at the policy that prevents foreign nationals from owning land, yet we observe that the government of SA endeavors to support its companies that invest in other parts of Africa. In this case, we find that the ANC-led government strives to establish and maintain friendships with the host countries of SA companies. However, the African consumer market remains inspiring with the projection of about $\$ 1.4$ trillion value by 2020 , including the estimated 128 million homes that are expected to have access to disposable income by 2020 (Elumelu \& Brenthurst, 2013). African markets remain the perfect location for SA investors, because they are safe in the direction of profit accumulation and are nearly competition free. In fact, the continental (African) economy is largely regarded as widely untapped. The projection is that by 2030 nearly $50 \%$ of the African population may dwell in urban areas. This projection on African market is enticing and lucrative in forecast, despite the threat to Africa's development which looms large. Some of the threats in African market may include corruption, poor infrastructural development, and weak social and economic systems including a severely maligned educational system (Owoye \& Bissessar, undated).

In a swift bid to acquire a fair share of the African market and for the fact that SA has the capacity, in 2009, it invested \$1.6 billion in African markets. For example, in telecommunications; MTN SA has now dominated the industry in Africa through its operations in more than 21 countries in the region (Elumelu \& Brenthurst, 2013; Umezurike, 2015).

\section{Conclusion}

The widespread opinion is that SA's neo-liberal economic policy depicts it as a sub-imperial state in the continent of Africa. While this position is debatable among scholars and analysts, it is commonly understood that business practices of South African firms have firmly entrenched it as an imposing partner through its attempt to craft unequal relations with other states in Africa mostly in SADC sub-region. Many are of the view that SA is an emerging power, capitalist or hegemony particularly in its relations with SADC sub-region due to its FDI activities (Habib \& Langsberg, 2003; Mandela, 2010). Bond (2006) made the case that SA's anti-imperialism has no chance to change the world, but puts the country on the track to join the established global order - or simply put a 'comprador' state. In fact, he wrote:

Pretoria's reformers are, at the same time, both 'compradors,' i.e., agents of the global establishment - and failures, when it comes to delivering its adopted policy positions.

This paper tends towards these assumptions, albeit we have paid special attention to the SA's economic relations with SADC states particularly from 1994 to 2016. The paper's emphasis is on the areas of trade, FDI, electricity sharing, custom service and private sector roles of SA in Southern African subregion. The theoretical assumptions that underline SA's relations with SADC countries have been juxtaposed with the role of SA in the sub-regional economy including especially its leadership in economics and politics in Southern Africa. Thus, the paper concludes that SA's economic relations with SADC are clearly shaped by its economic interests to serve its broad national interests through the forces of capital globalization that have shaped its political economy from the beginning of its neoliberal reform in 1994. The neo-liberal political economy is appropriate in an attempt to capture and analyze SA's relations with SADC states notwithstanding the fact that the approach may record some shortcomings. The paper, by applying empirical evidence, demonstrates that the notion in 
scholarly literature that SA's economic prosperity has already shaped and positioned it in Africa as a neo-imperialist is merely overrated, but likely on course towards that. SA does not have the leverage to dictate for its immediate neighbors because of its own limitations including especially such factors as poverty, disease, lack of resources for its reconstruction projects, and its unwillingness to lead Africa in any direction or into prosperity (see Umezurike, 2015). In other words, SA's trade and investment activities in Africa have not improved the socio-economic conditions of the continent.

However, the relationship between SA and Southern African states has the characteristics of cooperation, but typically with a South African advantage. On general terms, the co-operation has not reflected positively in the socio-economic condition of Africa or in the way Africa is viewed in the global power configuration. SA remains the economic power hub of SADC, as well as SADC's most pivotal state. The rich historical bonds between SA and SADC group need not to be overemphasized since the end of racial segregation in the country. SA's practice of democracy and neoliberalism since 1990s (Bond, 2006), brought collective economic values to SADC states in many perspectives under the auspices of SADC, SACU and SAPP, but SA's overbearing influence in the sub-region is clearer in FDI, as the groups of SADC, SACU and SAPP provide cover for South African economic ambition.

SA's relations with SADC countries are identical to the expansion of its home grown firms, but, to some extent, mutual co-operation underlines it, as this led to SA producing about $80 \%$ of SADC GDP beginning from 1994 when it became a democratic state. The process of SA and SADC symbiotic relations in economics may be described as both cooperative and dominance, because, while SA has overbearing influence on economics of the subregion, it uses co-operation with sovereign states to continue operating its businesses successfully in the sub-region. Nkomo (2006) wrote:

'South Africa has the most developed, diversified and self-driven economy, with the gross domestic product (GDP) that is more than double of the other Southern African countries combined'.

Thus, in closing, we submit that the prospects of socio-economic development in Southern Africa rely mostly on the role of SA in economic and political diplomacy in the region. We affirm this given that SA has the largest and fastest growing investment in the SADC and the region is the most crucial partner of SA business groups.

\section{References}

1. African Economic Outlook. (2014). Global Value Chains and Africa's Industrialization OECD Development Centre.

2. Alden, C. and Schoeman, M. (2013). South Africa in the Company of Giants: the Search for Leadership in a Transforming Global Order, International Affairs, 89 (1), pp. 111-129.

3. Alden, C. and Pere, G. (2009). South Africa - bound to lead, Politikon: South African Journal of Political Studies, 36(1), pp. 145-169.

4. Alden, C. and Soko, M. (2005). Africa's economic relations with Africa: hegemony and its discontents, Journal of Modern African Studies, 43(3), pp. 367-392.

5. Alden, C. and Maxi Schoeman, M. (2015). South Africa's Symbolic Hegemony in Africa, International Politics, 52(2), pp. 239-254.

6. Aldrich, T. (2000). The Southern African Power Pool: Meeting the Sub-continent's electricity needs, 3, Institute of Global Dialogue.

7. Aremu, I. (2013). Africa: Wither Whither South Africa-Nigeria Bi-national Commission? Daily Trust, http://allafrica.com/stories/201305200417.html, Accessed July 18, 2013.

8. Bond, P. (2006). Talk Left, Walk Right. South Africa's Frustrated Global Reforms. Second edition http://ccs.ukzn.ac.za/files/BondTalkLeftWalkRight2ndedn.pdf, accessed on 27/04/2015.

9. Bond, P. (2013). Sub-imperialism as Lubricant of Neoliberalism: South African 'deputy sheriff duty within BRICS, Third World Quarterly, 34(2), pp. 251-270.

10. Borer, T.A. and Mills, K. (2011). Explaining Post-apartheid South African Human Rights Foreign Policy: Unsettled Identity and Unclear Interests, Journal of Human Rights, 10(1), pp. 76-98.

11. Chidozie, C.F. et al. (2015). Deregulation of the Nigerian Telecommunication Sector: Interrogating the Nexus between Imperialism and Development, Academic Journal of Interdisciplinary Studies, 4(1), pp. 173-184.

12. Dey, I. (2005). Qualitative data analysis. London: Routledge, Taylor and Francis Group.

13. Draper, P., Halleson, D. and Alves, P. (2007). SACU, Regional Integration and the Overlap Issue in Southern Africa: From Spaghetti to Cannelloni? Trade Policy report no. 15 South African Institute of International Affairs.

14. Du Plessis, S. and Smit, B. (2007). South Africa's growth revival after 1994. Stellenbosch Economic Working Papers. Department of Economic and Bureau of Economic Research, University of Stellenbosch.

15. Du Plessis, S. and Smit, B. (2005). Economic Growth in South Africa Since 1994. Stellenbosch Economic Working Papers. Department of Economic and Bureau of Economic Research, University of Stellenbosch. 
16. Economic Consulting Associates. (2009). The Potential of Regional Power Sector Integration Southern African Power Pool (SAPP). Transmission \& Trading Case Study Submitted to ESMAP.

17. Elumelu and Brenthurst. (2013). Africans Investing in Africa Building Prosperity Through Intra-African Trade and Investment. Discussion Paper 2/2013. Co-produced by The BrenthurstFoundation and The Tony Elumelu Foundation.

18. Ernst and Young. (2013). Ernst \& Young's attractiveness surveys, 2013, Growing beyond Africa.

19. Games, D. (2003). The South African Institute of International Affairs Business in Africa Research Project. The Experience of South African Firms Doing Business in Africa. A Preliminary Survey and Analysis, SAIIA's Business in Africa Project.

20. Habib, A., Langsberg, C. (2003). Presented at a public debate held during organised by the Centre for Policy Studies, in conjunction with the Open Society Foundation of South Africa.

21. Labor Research Service. (2010/2011). South African mncs in Africa - Trends in 2010 / 2011, report covering MNCs submitted by Global Unions.

22. Leary, D.T., Charpentier, J. and Minnogue, D. (1998). The World Bank Group B Finance, Private Sector, and Infrastructure Network Promoting Regional Power Trade - The Southern African Power Pool.

23. Mandela, B.T. (2010). Regional Hegemony as a Tool for Peace: An evaluation of South Africa's Role in Regional Development through the Spatial Development Initiatives. Thesis to Stellenbosch University. Stellenbosch.

24. Matsoso, L.M. and Iwu, C.G. (2016). Women and small scale entrepreneurship: perspective from the SADC. In Introduction to gender studies in Eastern and Southern Africa. A reader. Etim, James (ed). The Netherlands: Sense Publishers.

25. Mbeki, T. (2003). Address to the National Council Of Provinces, 11 November 2003. http://www. sahistory.org.za/archive/address-national-council-provinces-11-november-2003.

26. Merven, B. and Gielen, D. (2012). Southern African and Western African Power Pool Models for Capacity Building and Preliminary Analysis of the role of Renewable Electricity Generation at Country Level in a Regional Context, IRENA.

27. Mogalakwe, M. (2006). Research Report. The Use of Documentary Research Methods in Social Research, African Sociological Review, 10(1), pp. 221-230.

28. Moolman, C.E., Roos, E.L., Le Roux, J.C. and Du Toit, C.B. (2006). Foreign Direct Investment: South Africa's Elixir of Life? Department of Economics Working Paper Series, University of Pretoria.

29. Nathan, L. (2005). Consistency and inconsistencies in South African foreign Policy, International Affairs, 81(2), pp. 361-372.

30. Ncube, M., Shimeles, A. and Verdier-Chouchane, A. (2012). South Africa's Quest for Inclusive Development. Working Paper Series No 150 African Development Bank, Tunis, Tunisia, pp. 1-28.

31. Ndlovu, S.M. (2010). Sports as cultural diplomacy: the 2010 FIFA World Cup in South Africa's foreign policy, Soccer and Society, 11 (1-2), pp. 144-153.

32. Nkomo, J.C. (2006). The Impact of Higher Oil Prices on Southern African Countries, Journal of Energy in Southern Africa, 17(1), pp. 1-17.

33. Owoye, O. and Bissessar, N. (Undated). Bad Governance and Corruption in Africa: Symptoms of Leadership and Institutional Failure.

34. Payne, G. and Payne, J. (2004). Key Concepts in Social Research. London: Sage Publications.

35. Rothkegel, L. (2013). The Power of Power: Regime Dynamics and the Southern African Power Pool. Thesis submitted to University of Stellenbosch, Stellenbosch.

36. Scott, D.B., Szöcs, O., Ramuhashi, E., Seedat, M., Finnemore, R., Masangane, B. and Jeftha, J. (2011). KPMG's Global Infrastructure \& Projects Group Africa Team, Johannesburg, South Africa. In collaboration with: Global Power \& Utility Centre of Excellence in Budapest, Hungary.

37. The International Bank for Reconstruction and Development/the World Bank. (2011). South Africa Economic Update - Focus on Savings, Investment, and Inclusive Growth, pp. 1-60.

38. Umezurike, S.A. (2015). South Africa's Economic Policy towards Africa: Renaissance or Neo-imperialism? Unpublished Thesis, University of Zululand, KwaDlangezwa, South Africa.

39. UNCTAD. (2005). Case Study on Outward Foreign Direct Investment by South African Enterprises. United Nations Conference on Trade and Development: Geneva. [http://www.unctad.org/en/docs/c3em26d2a5_en.pdf]

40. Wannenburg, G. (2004). From Pariah to Pioneer: The Foreign Policy of the South African Police Service. South Africa's Foreign Policy 1994-2004. Apartheid Past, Renaissance Future: The South African Institute of International Affairs Johannesburg, pp. 169-168.

41. Wentworth, L. (2012). South Africa's Investment Landscape: Mapping Economic Incentives, Economic Diplomacy program. SAIIA Ocasional Paper.

42. Zobaa, A.F. (2005). Southern African Power Pools.

43. Zuma, J. (2014). Full text of President Jacob Zuma's state of the nation speech 2014. \#SONA2014, as provided by http://www.timeslive.co.za/politics/2014/06/17/full-text-of-president-jacob-zuma-s-state-of-the-nation-speech-2014sona2014 accessed on 19th 1st, 2015. 